\title{
Зональность измененных минерализованных пород на медно-молибденовом порфировом рудопроявлении Пеллапахк
}

Калинин А.А.

Геологический институт КНЦ РАН, Anamumb, kalinin@geoksc.apatity.ru

\begin{abstract}
Аннотация. На медно-молибденовом рудопроявлении Пеллапахк установлена следующая зональность измененных пород: (0) - слабоизмененные гранит-порфиры, (1) - микроклин-кварцевые и кварцмикроклиновые породы, (2) - кварц-мусковитовые и мусковит-кварцевые сланцы, (3) - кианит (андалузит)мусковит-кварцевые сланцы, (4) - жедрит-кордиеритовые породы по сланцам поросозерской серии, (5) - слабоизмененные андалузит-биотитовые плагиосланцы поросозерской серии. Такая зональность близка к зональности, описанной в порфировых месторождениях в фанерозойских комплексах. Показано, что формирование зональности на рудопроявлении происходило при развитии порфировой рудной системы, впоследствии измененные породы были метаморфизованы. Рудный штокверк имеет сложную форму и охватывает различные типы измененных пород.
\end{abstract}

Ключевые слова: пояс Колмозеро-Воронья, порфировые месторождения, метасоматоз, сульфидная минерализация.

\section{Zoning of altered rocks in the Pellapahk copper-molybdenum porphyry occurrence}

\author{
Kalinin A.A. \\ Geological Institute of the Kola Sci.Centre, RAS, Apatity, kalinin@geoksc.apatity.ru
}

\begin{abstract}
The following zoning of altered rocks was defined in the Pellapahk Cu-Mo occurrence: (0)-unaltered ganite porphyry; (1) - microcline-quartz and quartz-microcline rocks; (2) - quartz-muscovite and muscovite-quartz schists; (3) - quartz-muscovite-kyanite(andalusite) schist; (4) - cordierite-gedrite rock after prosozero series schists; (5) - unaletered biotite-andalusite schist of the porosozero series. The defined zoning is similar to that one, described in the porphyry $\mathrm{Cu}$ deposits in Phanerozoic. The alteration zonality formed at the time of development of the porphyry ore system in the Pellapahk occurrence, and later the altered rocks were amphibolite facies metamorphosed. The mineralized stockwork is of very complicated form, and different altered rocks are mineralized.
\end{abstract}

Key words: Kolmozero-Voronya belt, porphyry deposit, alteration, sulfide mineralization.

В поясе Колмозеро-Воронья известно более 20 массивов, относящихся к комплексу габбродиоритов - диоритов - гранодиорит-порфиров, они сосредоточены в северо-западном фрагменте пояса. Порфиры основного - среднего состава образуют дифференцированные от габбродиорит-порфиров до гранит-порфиров массивы размером менее 1 км по длинной оси. Порфировые породы кислого состава (гранодиорит- и гранит-порфиры) могут формировать и более крупные массивы до нескольких километров по длинной оси, но менее дифференцированные по составу. Наиболее значительные из них это массив у северного подножия горы Пеллапахк и массив в истоках р. Няльмйок.

С породами комплекса габбродиоритов - диоритов - гранодиорит-порфиров в северозападной части зеленокаменного пояса ассоциируют медно-молибденовое рудопроявление Пеллапахк, месторождение золота Няльм-1 и золото-серебряное месторождение Оленинское.

Гранит-порфиры г. Пеллапахк интрудируют основные и средние метавулканиты колмозерской серии, а также высокоглиноземистые сланцы поросозерской серии, что подтверждается секущим характером контактов гранит-порфиров и наличием ксенолитов сланцев поросозерской серии в южной части интрузии. В свою очередь, кварцевые порфиры в северной части тела секутся интрузией плагиомикроклиновых гранитов, а также многочисленными малыми интрузиями и дайками пироксенитов, габбро и габбро-долеритов, пегматитовыми жилами, протерозойскими и палеозойскими дайками оливиновых и пикритовых порфиритов (Калинин, Галкин, 2012) (рис. 1). 


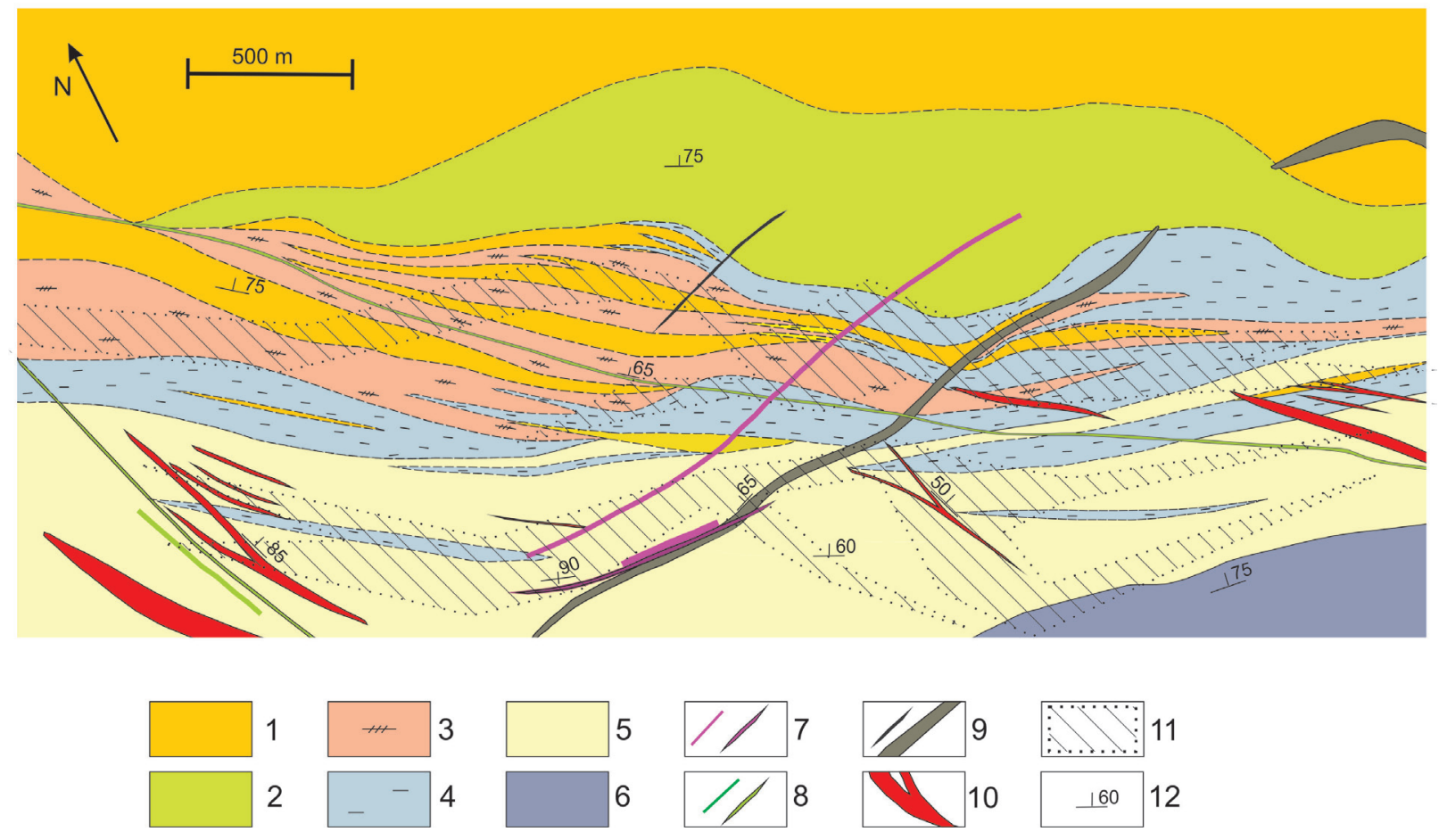

Рис. 1. Схематическая геологическая карта Cu-Мо рудопроявления Пеллапахк (по Калинин, Галкин, 2012).

1 - гранит-порфиры, 2 - перемежающиеся кварцевые порфиры, амфиболиты, биотит-амфиболовые и биотитовые плагиосланцы неясного генезиса; 3 - кварц-полевошпатовые и полевошпат-кварцевые породы, 4 - кварцмусковитовые и мусковит-кварцевые сланцы; 5 - кианит (андалузит)-мусковит-кварцевые сланцы; 6 - жедриткордиеритовые метасоматиты по глиноземистым сланцам поросозерской серии; 7 -дайковый комплекс пикритовых порфиритов и щелочных пикритов (PZ?); 8-9 -дайковый комплекс (PR?): 8 - долериты, 9 - пироксениты; 10 - жилы гранитных пегматитов; 11 - границы продуктивного штокверка с Cu-Мо минерализацией; 12 - элементы залегания (сланцеватость, контакты жил и даек).

Fig. 1. Schematic geological map of the Pellapahk Mo-Cu occurrence (after Калинин, Галкин, 2012).

1 - granite porphyry, 2 - interstratifications of quartz porphyry, amphibole-biotite and biotite plagioschists of unclear genesis, 3 - quartz-feldspar and feldspar-quartz rocks, 4 - quartz-muscovite and muscovite-quartz schists; 5 - quartzmuscovite-kyanite(andalusite) schist; 6 - cordierite-gedrite rock after the Porosozero series schists, 7-dykes of alkaline picrite and picrite porphyry (PZ?), 8 - dolerite dykes (PR?), 9 - pyroxenite dykes (PR?), 10 - granite pegmatite veins, 11 - Cu-Mo mineralized stockwork, 12 - rock bedding (schistosity, contacts of dykes and veins).

Возраст интрузии гранит-порфиров, определенный классическим U-Pb методом по циркону, составил $2828 \pm 8$ млн. лет, СКВО = 0.86 (Калинин и др., 2010). То есть внедрение кварцевых порфиров связано с завершающей стадией формирования вулканогенно-осадочных пород пояса, до регионального метаморфизма амфиболитовой фации который имел место в неоархее и в палеопротерозое (Другова и др., 1982).

Гранит-порфиры - мелкозернистые до тонкозернистых породы с порфировыми вкрапленниками кварца и плагиоклаза размером до 1 мм. Минеральный состав порфиров: кварц 40-45 \%, плагиоклаз - олигоклаз-андезин 25-35 \%, микроклин до 10 \%, мусковит 10-15 \%, биотит 5-10 \%, кальцит и эпидот до 2-3 \%; акцессорные минералы представлены титанитом, рутилом, турмалином, апатитом, сульфидными минералами - пиритом, пирротином, халькопиритом и сфалеритом. По химическому составу порода относится к умеренно-глиноземистым интрузивным породам І-типа известковощелочного ряда (Kalinin, Kudryashov, 2021).

Измененные породы развиваются в виде полосы мощностью около 700 метров вдоль границы кварцевых порфиров и высокоглиноземистых сланцев поросозерской серии. Отмечается следующая последовательность смены одних типов пород другими (с севера на юг, рис. 1): (0) - слабоизмененные гранит-порфиры, (1) - микроклин-кварцевые и кварц-микроклиновые породы, 
(2) - кварц-мусковитовые и мусковит-кварцевые сланцы, (3) - кианит (андалузит)-мусковиткварцевые сланцы, (4) - жедрит-кордиеритовые породы по сланцам поросозерской серии, (5) - слабоизмененные андалузит-биотитовые плагиосланцы поросозерской серии.

Мусковитовые и кианит-мусковитовые сланцы - тонко-мелкозернистые породы серебристобелого цвета. Присутствуют порфировые вкрапленники кварца, унаследованные от исходных пород (4 об. \%), и порфиробласты глиноземистых минералов (6-8 \%). Основная масса кианит (андалузит)мусковитовых сланцев состоит из кварца 50-60 об. \%, мусковита 5-20 \%, андалузита и кианита 2-25 \%, плагиоклаза до $10 \%$, биотита до $5 \%$, иногда присутствуют силлиманит (фибролит), кордиерит, турмалин, рутил, сфен, апатит. В зависимости от наличия той или иной полиморфной модификации силиката алюминия выделяются кианитовые, кианит-андалузитовые и андалузитовые разности сланцев.

В процессах преобразования полевые шпаты исходных пород были замещены мусковитом и кварцем, биотит - мусковитом, и появились новообразованные минералы глинозема андалузит и кианит. Изменение химического состава гранит-порфиров выразилось в увеличении содержания $\mathrm{SiO}_{2}$ и $\mathrm{K}_{2} \mathrm{O}$, в снижении $\mathrm{MgO}, \mathrm{CaO}$ и $\mathrm{Na}_{2} \mathrm{O}$ (Белолипецкий и др., 1987). При этом магнием и кальцием обогащены жедрит-кордиеритовые метасоматиты, развивающиеся по сланцам поросозерской серии на контакте с гранит-порифрами - по всей видимости, имело место переотложение указанных коипонентов.

Известно, что для порфировых месторождений в фанерозойских комплексах свойственна следующая обобщенная зональность (от центра к краю системы и снизу вверх): зоны кальциевонатриевого, калиевого метасоматоза, хлорит-серицитовая, серицитовая и зона аргиллитизации (пирофиллит-кварцевые, алунит-кварцевые, каолинит-кварцевые породы) (Sillitoe, 2010). Выделяемая нами на рудопроявлении Пеллапахк зона микроклин-кварцевых пород соответствует зоне калиевого метасоматоза, мусковит-кварцевых сланцев - серицитовой зоне, а кианит (андалузит)мусковит-кварцевые сланцы - зона аргиллитизации пород. Таким образом, зональность измененных пород на рудопроявлении сходна с таковой в порфировых месторождениях фанерозоя, но только с учетом преобразования метасоматических пород при наложенном региональном метаморфизме амфиболитовой фации, когда серицит был замещен мусковитом, а гидросиликаты алюминия пирофиллит, каолинит, алунит - андалузитом, по которому впоследствии развивался кианит. Следует заметить, что гипотеза о происхождении кианит-мусковитовых сланцев в результате метаморфизма измененных вулканогенных пород ранее была предложена А.А. Глаголевым (1976), когда данный объект еще не рассматривался как рудопроявление меди и молибдена.

Продуктивная минерализация $\mathrm{Cu}$ и Мо на рудопроявлении связана с минерализованным штокверком кварцевых и кальцит-эпидот-кварцевых прожилков, охватывающим измененные породы разного состава. Рудный штокверк имеет достаточно сложную форму, протяженность штокверка более 1500-1600 м при ширине от 350 до 600 м (рис. 1). На глубину минерализация прослежена в северо-западной части штокверка до отметки 360 м (Калинин, Галкин, 2012).

В составе минерализации установлены основные рудные минералы пирит, халькопирит и рутил, второстепенные молибденит, сфалерит, галенит, тетраэдрит, пирротин, кубанит, ильменит, шеелит, редкие - самородный висмут, гудмундит, теннантит, леллингит, лиллианит, пентландит (Калинин, Галкин, 2012, Белолипецкий и др., 1987). Более 90 \% сульфидной массы приходится на пирит.

Минерализация халькопирита и молибденита отмечается как в прожилках, так и в основной мелкозернистой массе породы в виде рассеянной тонкой вкрапленности. Содержание Мо варьирует от 0.01 до $0.11 \%$ (среднее по рудопроявлению 0.028 \%), содержание меди от 0.1 до $0.7 \%$, среднее по рудопроявлению 0.154 \%. Наиболее важным из попутных компонентов является серебро, содержание которого в руде 2.0 г/т.

Геохимическая ассоциация элементов в минерализованных породах включает $\mathrm{Mo}, \mathrm{Cu}, \mathrm{Ag}$, $\mathrm{Bi}, \mathrm{W}, \mathrm{Se}$ и $\mathrm{Sb}$, при этом содержание $\mathrm{Cu}, \mathrm{Mo}, \mathrm{Bi} \mathrm{W}$ в 10 и более раз выше, чем в исходных гранитпорфирах (Kalinin, Kudryashov, 2021).

Поскольку минерализация рудопроявления Пеллапахк отнесена к порфировому типу (Калинин, Галкин, 2012), то формировалась она на стадии постмагматических гидротермально- 
метасоматических процессов, до регионального метаморфизма. Поэтому в породах рудопроявления Пеллапахк должны быть признаки метаморфизма руд. К таким признакам относится развитие чешуек молибденита по спайности мусковита, а халькопирита по трещинам спайности кианита, реже андалузита (рис. 2).
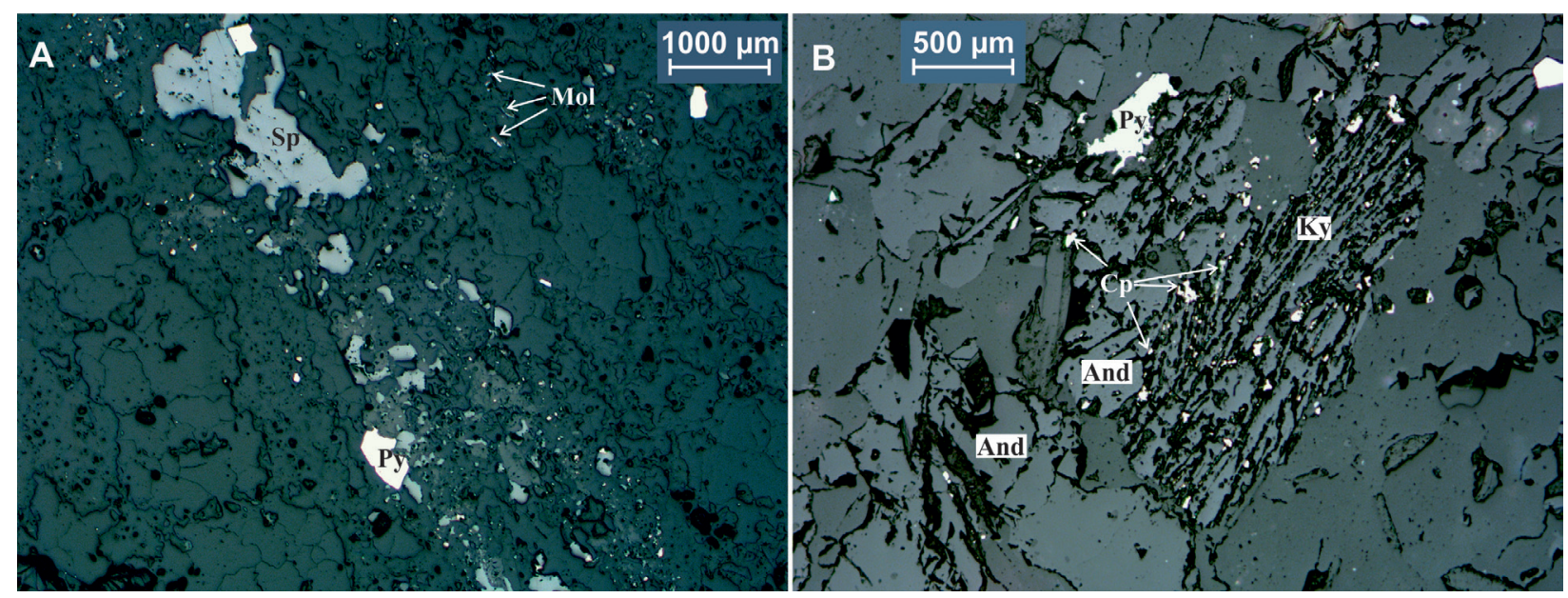

Рис. 2. А - Пирит-сфалеритовая с молибденитом минерализация в эпидот-кальцит-кварцевом прожилке. В - выделение халькопирита по трещинам спайности кианита. Фото аншлифов, без анализатора. And - андалузит, $\mathrm{Cp}$ - халькопирит, Ку - кианит, $\mathrm{Mol}$ - молибденит, Ру - пирит, $\mathrm{Sp}$ - сфалерит.

Fig. 2. A - Sphalerite-pyrite and molybdenite mineralization in quartz-calcite-epidote veinlet. B - chalcopyrite along cleavage in kyanite. Microscope photographs, plane polarized light. And - andalusite, $\mathrm{Cp}$ - chalcopyrite, Ky - kyanite, Mol - molybdenite, Py - pyrite, Sp - sphalerite.

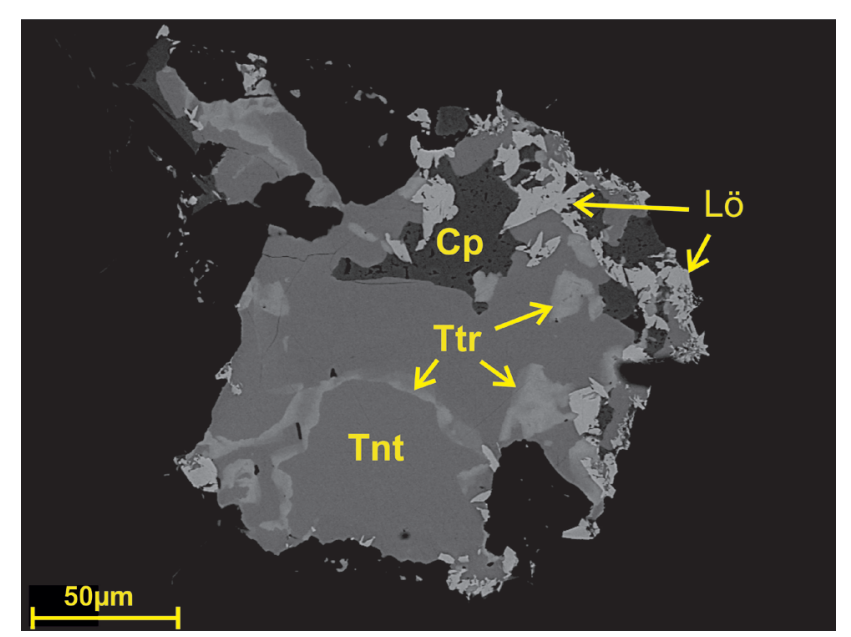

Рис. 3. Структура кристаллизации сульфидного расплава - срастание теннантита, тетраэдрита, леллингита и халькопирита. Фотография в обратно рассеянных электронах. Cp - халькопирит, Lo - леллингит, Td - тетраэдрит, Tnt - теннантит.

Fig. 3. Structure of sulfide melt crystallization-an aggregate of tennantite, tetrahedrite, chalcopyrite, and. Back scatteredelectronimage.Cp-chalcopyrite,Lo-löllingite, $\mathrm{Td}$ - tetrahedrite, $\mathrm{Tnt}$ - tennantite.

Одним из важных признаков метаморфизма руд в условиях амфиболитовой или гранулитовой фации является формирование структур кристаллизации сульфидного расплава (Frost et al, 2002, Tomkins, 2006). Достигнутая при метаморфизме пород в условиях нижней части амфиболитовой фации температура 500-600 ${ }^{\circ} \mathrm{C}$ (Другова и др., 1982) была выше пределов устойчивости некоторых минералов $\mathrm{Pb}, \mathrm{Bi}, \mathrm{As}, \mathrm{Sb}$, входящих в состав минерализации, что и привело к появлению названных структур. На рудопроявлении Пеллапахк к таковым можно отнести тонкое срастание галенита, лиллианита, самородного висмута, аргентотетраэдрита и сфалерита, описанное ранее в (Белолипецкий и др., 1987), а также срастание тетраэдрита, теннантита, халькопирита и леллингита, представленное на рисунке 3. Интересно отметить сам факт появления леллингита в богатой пиритом породе (это «запрещенная» минеральная ассоциация) при отсутствии арсенопирита. 


\section{Выводы}

Зональность измененных пород на рудопроявлении Пеллапахк соответствует зональности, характерной для порфировых месторождений в фанерозойских комплексах. Формирование зональности связано со временем развития порфирово-эпитермальной рудной системы в северо-западной части пояса Колмозеро-Воронья. Измененные оруденелые породы были впоследствии метаморфизованы в условиях амфиболитовой фации, и в настоящем виде они представлены обычными для метаморфических пород амфиболитовой фации минеральными ассоциациями.

Работа выполнена в рамках темы НИР № 0226-2019-0053.

\section{Литература}

1. Белолипецкий А.П., Калинин А.А., Петров С.И. Минералогия и геохимия метасоматитов зон глубинных разломов. Апатиты. Изд-во: Кольского филиала АН СССР. 1987. 115 с.

2. Глаголев А.А. Влияние ранних поствулканических процессов на состав метаморфических пород Вороньих тундр (Кольский полуостров) // Геохимия, минералогия и петрология. Кн. 5. София. Изд-во: Болгарской АН. 1976. С. 108-116.

3. Другова Г.М., Глебовицкий В.А., Дук В.Л., Кицул В.И, Савельева Т.Л., Седова И.С., Семенов А.П. Высокоградиентные режимы метаморфизма в развитии земной коры. Л. Изд-во: Наука. 1982. 229 с.

4. Калинин А.А., Галкин Н.Н. Докембрийское медно-молибден-порфировое месторождение Пеллапахк (зеленокаменный пояс Колмозеро-Воронья) // Вестник Кольского НЦ РАН. 2012. № 1. С. 80-92.

5. Калинин А.А., Кудряшов Н.М., Галкин Н.Н. Рудопроявления золота, меди и молибдена в зеленокаменном поясе Колмозеро-Воронья (Кольский полуостров): геологические особенности и возраст // Золото Кольского полуострова и сопредельных территорий. Апатиты. Изд-во: К\&M. 2010. С. 51-59.

6. Frost B.R., Mavrogenes J.A., Tomkins A.G. Partial melting of sulfide ore deposits during medium- and highgrade metamorphism // Can. Miner. 2002. V. 40. P. 1-18.

7. Kalinin A.A., Kudryashov N.M. Porphyry-related metamorphosed Au-Ag and Cu-Mo deposits in the Precambrian of the Fennoscandian Shield // Minerals. 2021. V. 11. C. 139. https://doi.org/10.3390/min 11020139.

8. $\quad$ Sillitoe R.H. Porphyry-copper systems // Econ. Geol. 2010. V. 105. P. 3-41.

9. Tomkins A.G., Frost B.R., Pattison D.R.M. Arsenopyrite melting during metamorphism of sulfide ore deposits // Can. Miner. 2006. V. 44. P. 1025-1042. 